Матеріали Всеукраїнської науково-практичної конференчії «Актуальні питання діагностики, лікування, раціональної фармакотерапії, диспансеризації та реабілітації в практиці сімейного лікаря»

DOI

\title{
ОЦІНКА ЕФЕКТИВНОСТІ ПРЕВЕНТИВНИХ ЗАХОДІВ У ХВОРИХ, ЯКІ ПЕРЕНЕСЛИ ГОСТРИЙ ПАНКРЕАТИТ
}

\author{
๑Т. Б. Лазарчук, О. Є. Самогальська, І. В. Мерецька
}

ДВНЗ «Тернопільський державний медичний університет імені І. Я. Горбачевського мОз України»

Вступ. Надзвичайна в Україні, порівняно із країнами Європи, захворюваність та поширеність хронічного панкреатиту (ХП) може пояснюватися як гіпердіагностикою ХП, так і більш високим рівнем споживання алкоголю як основної причини розвитку ХП [1]. Проте не слід ігнорувати профілактичну роботу у групах ризику ХП, здатну запобігти розвитку, рецидивуванню і прогресуванню патологічного процесу у підшлунковій залозі (ПЗ). Відповідно до класифікації клінічних стадій ХП за M-ANNHEIM [2], пацієнтів із епізодом гострого панкреатиту (ГП) в анамнезі (за відсутності симптомів $X П$, але за наявності факторів ризику (ФР)) слід віднести до групи субклінічного ХП Оb при відсутності структурних і функціональних змін П3, а отже планувати комплекс превентивних заходів щодо запобігання прогресуванню захворювання [3].

Мета. Оцінити ефективність профілактичних заходів щодо запобігання прогресуванню патологічного процесу в ПЗ у хворих, що перенесли епізод ГП (за даними первинної документації).

Матеріали і методи дослідження. Проаналізували медичні карти 74 хворих на ХП, що розвинувся після ГП, які перебували на стаціонарному лікуванні у 2015 році. Оцінювали ступінь структурних порушень ПЗ за критеріями Кембриджської класифікації ХП (1999), наявність ФР за класифікацією М-ANNHEIM (2007).

Результати й обговорення. За результатами аналізу виокремили дві групи: I (n=50) - хворі, які перенесли набрякову форму ГП (переважно 1 епізод ГП, в 16 \% - більше 1) і II ( $n=24)$ - хворі, які перенесли деструктивний ГП, із них прооперованих 35,7 \%. У І групі за домінувала легка форма паренхіматозного ХП, у II - кальцифікучий ХП діагностовано 79,2 \%, обструктивний - у 20,8 \%. Ретроспективний аналіз ФР у пацієнтів I групи засвідчив вживання алкоголю (оцінка балів за САGE та AUDIT) у $78 \%$, при цьому повна абстиненція зафіксована у 46,2 \%, часткова - у 30,8 \%, без змін -у 23,1 \%. Решта 11 хворих цієї групи заперечували вживання алкоголю (0 балів за СAGE). Тютюнокуріння зареєстровано у 56 \% хворих (більше 10 пачко/років - у 60,7 \%). Ступінь відмови від куріння встановити не вдалося. Проте, за даними медичних карт 9 (32 \%) осіб із цієї підгрупи стверджували повну відмову від куріння протягом не менше 1 року. Наступний ФР - незбалансоване харчуван- ня - оцінити не вдалося, проте порушення дієти і режиму харчування (у загальному вигляді) зафіксовано у 100 \% медичних карт. Патологія жовчовивідних шляхів і порушення властивостей жовчі (друга за частотою в Україні причина розвитку ХП) діагностована у 62 \%: холецистокалькульоз - у $29 \%$ (планова холецистектомія проведена у 2 осіб $(22,2 \%))$, мікрохолецистокалькульоз -у 45,2 \% (терапію препаратами урсодезоксихолевої кислоти на амбулаторному етапі отримували 35,7 \%, тривалість і достатність оцінити не вдалося), дисфункцію сфінктера Одді (панкреатичний тип) - у 25,8 \% (терапію мебеверином на амбулаторному етапі отримали 2 пацієнти, тривалість і достатність невідомі). Частота нападів жовчної коліки у цій підгрупі коливалася від 0 (22,5 \%) до 1 разу на 1-3 місяці, відмову від планової холецистектомії підписали 7 хворих із холецистокалькульозом (77,8 \%). Надлишкова вага і ожиріння переважно І стадії зафіксовано у 54 \% випадків, відомості про наявність та реалізацію програми нормалізації ваги відсутні. Про травми, пухлини органів черевної порожнини, імунологічні фактори, тяжкі захворювання інших органів і систем, медикаментозні та токсичні впливи у медичних картах не згадувалось. Найчастішими поєднаннями ФР були: вживання алкоголю і тютюнокуріння - 62 \%, ожиріння та патологія жовчовивідних шляхів - $46 \%$, вживання алкоголю та порушення ваги - 38 \%. У II групі прихильність хворих до модифікації способу життя була вищою через високу частоту абдомінального болю та функціональних порушень ПЗ.

Висновки. За динамікою відмови хворих, які перенесли набрякову форму ГП, від споживання алкоголю, тютюнокуріння, прихильністю до оздоровчих заходів ефективність превентивної терапії ХП слід вважати слабкою. Вирішення цієї проблеми, на нашу думку, знаходиться у площині мотивації кожної людини до здорового способу життя з одного боку, з іншого - у більш активній роботі лікарів первинної ланки надання медичної допомоги у частині профілактичної роботи по виявленню ранніх та прихованих форм захворювання і ФР.

Перспектива подальших досліджень полягає у детальному вивченні механізмів прогресування ХП та відпрацюванні ефективних методів профілактики. 